\title{
PENGARUH PENAMBAHAN TELUR TERHADAP KANDUNGAN ZAT GIZI, VOLUME PENGEMBANGAN DAN UJI KESUKAAN BLONDIES GARUT (Marantha arundinacea) SEBAGAI ALTERNATIF MAKANAN BAGI SINDROM AUTISME
}

\author{
Marsella Temala Dewi, Ninik Rustanti* \\ Program Studi Ilmu Gizi Fakultas Kedokteran Universitas Diponegoro \\ Jl.Dr.Sutomo No.14, Semarang, Telp (024) 8453708, Email : gizifk@undip.ac.id
}

\begin{abstract}
Background: Autism syndrome is a several brain part development deffect shown by communicating disruption. One of the causes for those effects is gluten and cassein consumption that stored in wheat flour and cow milk. Arrowroot flour desn't have any gluten contents and can subtituting wheat flour because it has similar nutrition content and physicochemical characteristic. Previous study shown that brownies can be made from wide range type of flour with 100\% subtitute level, meanwhile eggs addition can increase protein conten in blondies. Blon dies is one kind of brownies that didn't use dark chocolate and lot of children like it. Therefore the study to inventing a safe alternative food without gluten and casein for autism syndrome needs to be done.

Objective: To analize the effect from eggs addition to nutrient content, loaf volume and preference test of arrowroot blondies as an alternative food for autism syndrome.

Methods: This study is a randomized experimental one factorial design which is addition of eggs with four different percentage $(50 \%, 75 \%, 100 \%, 125 \%)$. The statistic data for nutrition content and loaf volume analized using One Way ANOVA followed by Tukey test. Meanwhile the preference test analized using Friedman test followed by Wilcoxon test.

Results: Blondies with the highest protein is blondies with $125 \%$ addition of eggs with 7,44 g per $100 \mathrm{~g}$. Blondies with 125\% addition of eggs donates 19,07\% from Recommended Dietary Allowance (RDA) for 4-6 years old and 16,53\% 7-9 years old children. The highest fat content stored in blondies with 50\% addition of eggs with 17,19 g per $100 \mathrm{~g}$. The highest carbohydrate stored in blondies with $50 \%$ addition with $43,39 \mathrm{~g}$ per $100 \mathrm{~g}$. The biggest loaf volume is from $50 \%$ addition of eggs. The addition of eggs doesn't have any effect to crude fiber, preference test for aroma and taste but doesn't effecting the texture and colour of blondies.

Conclusion: The addition of eggs increase protein and preference test of colour and texture, and also decrease fat, carbohydrate content and loaf volume significantly, but doesn't have any effect to crude fiber and preference test of aroma and taste of blondies. Based on the value of the content of nutrients and preference test, the best product is blondies with $100 \%$ addition of eggs.
\end{abstract}

Key Words: Arrowroot; blondies; nutrient content; loaf volume; preference test; autism syndrome

\begin{abstract}
ABSTRAK
Latar Belakang: Salah satu pemicu gejala sindrom autisme adalah konsumsi gluten dan kasein yang terdapat dalam tepung terigu dan susu. Tepung umbi garut merupakan salah satu bahan makanan yang bebas gluten dan dapat dimanfaatkan menjadi pengganti tepung terigu karena kandungan dan fisikokimianya yang mirip dengan tepung terigu, sedangkan penambahan telur bertujuan untuk meningkatkan kadar protein dalam blondies. Penelitian sebelumnya menunjukkan bahwa brownies dapat dibuat dari berbagai macam tepung non-terigu dengan tingkat substitusi hingga 100\%. Blondies merupakan jenis brownies yang tidak menggunakan coklat masak dalam pembuatannya dan disukai oleh anak-anak. Oleh karena itu penelitian mengenani pembuatan makanan yang aman bagi sindrom autisme perlu dilakukan.

Tujuan: Menganalisis pengaruh penambahan telur terhadap kandungan zat gizi, volume pengembangan dan uji kesukaan blondies garut sebagai alternatif makanan bagi sindrom autisme.

Metode: Merupakan penelitian eksperimental dengan rancangan acak lengkap satu faktor yaitu penambahan telur pada pembuatan blondies garut dengan empat taraf perlakuan (50\%, 75\%, 100\%, 125\%). Analisis statistik untuk kandungan zat gizi dan volume pengembangan menggunakan uji One Way ANOVA dilanjutkan dengan uji Tukey. Sementara analisis statistik untuk uji kesukaan menggunakan uji Friedman dilanjutkan dengan uji Wilcoxon.

Hasil: Blondies yang mengandung protein tertinggi adalah blondies dengan penambahan telur $125 \%$ yaitu $7,44 \mathrm{~g}$ per 100 g. Sumbangan blondies garut dengan penambahan telur sebanyak $125 \%$ terhadap AKG protein untuk anak usia 4-6 tahun sebesar 19,07\% dan untuk anak usia 7-9 tahun sebesar 16,53\%. Kandungan lemak tertinggi terdapat pada blondies dengan penambahan telur 50\% yaitu 17,19 g per $100 \mathrm{~g}$ blondies. Kandungan karbohidrat tertinggi terdapat pada blondies dengan penambahan telur $50 \%$ yaitu 43,39 g per $100 \mathrm{~g}$. Volume kembang tertinggi terdapat
\end{abstract}

${ }^{*}$ Penulis Penanggungjawab 
pada blondies dengan penambahan telur 50\%. Penambahan telur tidak berpengaruh terhadap serat kasar, aroma dan rasa tetapi berpengaruh terhadap warna dan tekstur blondies.

Simpulan: Penambahan telur berpengaruh secara bermakna terhadap peningkatan kadar protein dan uji kesukaan panelis akan warna dan tekstur, serta penurunan kadar lemak, karbohidrat, dan volume pengembangan, tetapi tidak berpengaruh terhadap kadar serat kasar dan uji kesukaan panelis akan aroma dan rasa blondies. Berdasarkan nilai kandungan zat gizi dan uji kesukaan, blondies terbaik adalah blondies dengan penambahan telur sebanyak $100 \%$.

Kata Kunci: umbi garut; blondies; kandungan zat gizi; volume pengembangan; uji kesukaan; sindrom autisme

\section{PENDAHULUAN}

Sindrom autisme merupakan gangguan perkembangan beberapa bagian otak seperti cerebrum dan hipotalamus yang ditunjukkan dengan gangguan kualitatif seperti kemampuan berinteraksi sosial, gangguan komunikasi dan kebiasaan melakukan suatu pola pikir, perilaku dan aktivitas yang repetitif. ${ }^{1}$ Sindrom ini dapat diketahui saat anak berusia minimal 18 bulan, dimana anak mulai berkembang secara aktif dalam berjalan atau berbicara. Pada tahun 1980 penyandang sindrom autisme di dunia diperkirakan mencapai 5 kasus per 10000 kelahiran, pada tahun 2000 mencapai 30 sampai 60 kasus per 10000 kelahiran, sedangkan pada tahun 2007 terus meningkat yaitu 110 kasus per 10000 kelahiran. $^{2}$ Data dari Departemen kesehatan pada tahun 2004 menunjukkan penderita sindrom autisme di Indonesia sebesar $0,2 \%$.

Beberapa penelitian menyebutkan konsumsi gluten dan kasein dapat memicu dan memperparah gejala yang muncul, hal ini disebabkan karena penderita sindrom autisme tidak memiliki enzim utama DPP-IV (dipeptidylpeptidase IV) untuk mencerna protein tersebut secara sempurna. ${ }^{3}$ Penelitian pada tahun 2001 terhadap 120 anak dengan sindrom autisme menunjukkan sebanyak $84 \%$ anak memiliki alergi susu sapi dan gluten, $15 \%$ anak memiliki alergi susu sapi saja dan $2 \%$ anak memiliki alergi gluten dan makanan lain, sehingga disarankan diet bebas gluten dan kasein. ${ }^{4}$ Oleh karena itu perlu dibuat produk bebas gluten dan kasein yang dapat diperoleh dari umbi garut dan telur sebagai sumber protein.

Umbi garut selain merupakan salah satu sumber karbohidrat yang tidak mengandung gluten, tetapi kandungan gizi dan sifat fisiko kimianya mirip dengan tepung terigu. Dengan demikian tepung umbi garut dapat dimanfaatkan menjadi pengganti tepung terigu. ${ }^{5}$ Umbi garut juga memiliki beberapa kelebihan bila dibandingkan dengan pati dari umbi lainnya seperti ganyong dan singkong. Pati garut lebih mudah dicerna dengan daya cerna mencapai $90 \%$, sedangkan ganyong dan singkong hanya $75 \%$. Selain itu umbi garut memiliki kandungan gizi yang cukup tinggi sebagai bahan pangan yaitu $1,0 \%$ protein, $0,2 \%$ lemak, $24 \%$ karbohidrat, $0,6 \%-1,3 \%$ serat, $1,3 \%$ $1,4 \%$ kadar abu, $1,7 \%$ zat besi $3 \%$ fosfor dan $2,8 \%$ kalsium. $^{6}$

Pada produk yang dibuat dari bahan baku umbi garut diperlukan bahan lain sebagai sumber protein yaitu telur. Telur merupakan salah satu sumber protein hewani yang mudah ditemui, ekonomis dan sering dikonsumsi masyarakat. Kandungan gizi telur cukup lengkap yaitu 12,8\% protein, $11,5 \%$ lemak, $0,7 \%$ karbohidrat, $0,3 \%$ zat besi, $1,8 \%$ fosfor $0,54 \%$ kalsium, dan $9 \%$ vitamin A, dengan susunan asam amino essensial yang hampir sempurna. ${ }^{6}$ Net Protein Utilization (NPU) telur bernilai 94, sedangkan Protein Efficiency Ratio (PER) sebesar 3,92\%. Hal ini menunjukkan bahwa protein dalam telur mudah dicerna dalam tubuh.

Produk yang dianggap cocok untuk sindrom autisme dengan bahan baku tepung umbi garut dan telur sebagai sumber protein adalah brownies. Penelitian sebelumnya menunjukkan bahwa brownies dapat dibuat dari berbagai macam tepung non-terigu dengan tingkat substitusi hingga $100 \% .^{8}$ Akan tetapi anak dengan sindrom autisme tidak dapat mengkonsumsi coklat yang mengandung fenol karena kurangnya enzim phenil sulfo transferase dalam pencernaannya. ${ }^{9}$ Dengan demikian perlu produk lain yang tidak menggunakan coklat masak yaitu blondies yang mempunyai struktur mirip seperti brownies tetapi tidak menggunakan coklat masak dalam pembuatannya sehingga dapat dikonsumsi anak dengan sindrom autisme. Penambahan telur dalam produk blondies ini selain untuk memperbaiki tekstur, rasa dan aroma juga dapat meningkatkan nilai gizi yang terkandung di dalamnya. ${ }^{5}$ Penggunaan madu sebagai pengganti gula pasir, karena madu termasuk dalam bahan pemanis yang diperbolehkan untuk sindrom autisme, sedangkan penambahan pasta pandan bertujuan untuk menyamarkan bau amis pada telur. 
Berdasarkan latar belakang tersebut maka dilakukan penelitian mengenai kandungan zat gizi, volume pengembangan dan uji kesukaan blondies garut sebagai alternatif makanan bagi sindrom autisme.

\section{METODA}

Dari segi keilmuan, penelitian yang dilakukan merupakan penelitian dalam bidang Food Production, yang dilaksanakan pada bulan Juli hingga Agustus 2012 di Laboratorium Gizi Universitas Muhammadiyah Semarang dan Laboratorium Ilmu Pangan Universitas Katholik Soegijapranata Semarang.

Penelitian ini merupakan penelitian eksperimental dengan rancangan acak lengkap satu faktor yaitu penambahan telur pada pembuatan blondies garut dengan empat taraf perlakuan meliputi (1) penambahan telur 50\%, (2) penambahan telur $75 \%$, (3) penambahan telur $100 \%$, dan (4) penambahan telur $125 \%$. Keempat formulasi didapatkan melalui perbandingan berat total bahan dengan penambahan telur dan mempertimbangkan perhitungan kandungan protein agar dapat mencukupi kebutuhan protein sehari anak sampai dengan $40 \%$. Setiap formulasi dilakukan enam kali ulangan dan diuji secara simplo, sedangkan uji kesukaan blondies garut dilakukan satu kali tanpa pengulangan.

Blondies garut dibuat menggunakan bahan baku tepung umbi garut, telur, madu, margarin dan essens pandan. Tepung umbi garut yang dipakai didapatkan dari Gerai Pangan Gizi Yogyakarta dengan spesifikasi terbuat dari umbi garut varietas Creole, berwarna putih, tanpa rasa, kering, lolos ayakan 100 mesh, dan dikemas dalam kemasan plastik.

Pada penelitian utama, data yang dikumpulkan adalah kandungan gizi meliputi protein, lemak, serat kasar, karbohidrat, volume pengembangan dan uji kesukaan blondies garut.
Kadar protein diukur dengan menggunakan metode Macro-Kjedahl, ${ }^{10}$ kadar lemak diukur dengan menggunakan metode Soxhlet ${ }^{10}$ serat kasar diukur dengan mengunakan metode gravimetri, karbohidrat dihitung dengan metode by difference, volume pengembangan diukur dengan mengunakan metode seed displacement ${ }^{11}$ dan uji kesukaan didapatkan melalui uji hedonik menggunakan 5 rentang skala dengan skor 5 yaitu sangat suka, 4 yaitu suka, 3 yaitu netral, 2 yaitu tidak suk dan 1 yaitu sangat tidak suka. Uji kesukaan dilakukan pada panelis agak terlatih sebanyak 20 orang mahasiswa program studi Ilmu Gizi Universitas Diponegoro. Pengaruh penambahan telur terhadap kandungan gizi, dan volume pengembangan diuji dengan menggunakan one way ANOVA dan untuk mengetahui beda nyata antar perlakuan digunakan uji lanjutan yaitu uji Tukey. Sementara untuk mengetahui pengaruh terhadap uji kesukaan diuji dengan menggunakan uji Friedman dan dilanjutkan dengan uji Wilcoxon untuk mengetahui beda nyata antar perlakuan.

\section{HASIL}

\section{Kadar Protein Blondies Garut}

Hasil uji kadar protein blondies garut dengan formulasi penambahan telur yang memiliki kadar protein tertinggi adalah blondies dengan penambahan telur $125 \%$, sedangkan kadar protein terendah adalah blondies dengan penambahan telur $50 \%$. Dilihat secara keseluruhan kadar protein blondies meningkat seiring dengan meningkatnya persentase penambahan telur. Hal ini didukung dengan uji statistik kadar protein blondies yang menunjukkan bahwa ada pengaruh persentase penambahan telur terhadap peningkatan kadar protein dengan $\mathrm{p}=0,000$. Hasil analisa kadar protein blondies dengan penambahan telur secara singkat dapat dilihat pada Tabel 1 .

Tabel 1. Hasil Analisis Protein Blondies Garut Dengan Formulasi Penambahan Telur

\begin{tabular}{cc}
\hline Formulasi Penambahan telur & Kadar Protein (\%berat basah) \\
\hline $50 \%$ & $4,06 \pm 0,32^{\mathrm{c}}$ \\
$75 \%$ & $4,86 \pm 0,37^{\mathrm{bc}}$ \\
$100 \%$ & $6,79 \pm 0,26^{\mathrm{ab}}$ \\
$125 \%$ & $7,44 \pm 2,35^{\mathrm{a}}$ \\
\hline
\end{tabular}

2. Kadar Lemak Blondies Garut

Blondies garut dengan formulasi penambahan telur yang memiliki kadar lemak tertinggi adalah blondies dengan penambahan telur $50 \%$, sedangkan kadar lemak terendah adalah blondies dengan penambahan telur $100 \%$. Hasil uji statistik menunjukkan ada pengaruh persentase penambahan telur 
terhadap kadar lemak dengan $\mathrm{p}=0,008$. Hasil analisa kadar lemak blondies dengan penambahan telur secara singkat dapat dilihat pada Tabel 2.

Tabel 2. Hasil Analisis Lemak Blondies Garut Dengan Formulasi Penambahan Telur

\begin{tabular}{cc}
\hline $\begin{array}{l}\text { Formulasi Penambahan } \\
\text { telur }\end{array}$ & Kadar Lemak (\%berat basah) \\
\hline $50 \%$ & $17,19 \pm 1,25^{\mathrm{a}}$ \\
$75 \%$ & $15,90 \pm 0,29^{\mathrm{ab}}$ \\
$100 \%$ & $15,61 \pm 0,44^{\mathrm{b}}$ \\
$125 \%$ & $15,66 \pm 0,84^{\mathrm{b}}$ \\
\hline
\end{tabular}

3. Kadar Serat Kasar Blondies Garut

Kadar serat kasar pada blondies garut dengan formulasi penambahan telur yang tertinggi adalah blondies dengan penambahan telur $75 \%$, sedangkan kadar serat kasar terendah adalah blondies dengan penambahan telur 50\%. Hasil uji kadar serat kasar blondies menggunakan uji statistik menunjukkan bahwa ada tidak ada pengaruh persentase penambahan telur terhadap kadar serat kasar dengan $\mathrm{p}=0,817$. Hasil analisa kadar serat kasar blondies dengan penambahan telur secara singkat dapat dilihat pada Tabel 3 .

Tabel 3. Hasil Analisis Serat Kasar Blondies Garut Dengan Formulasi Penambahan Telur

\begin{tabular}{cc}
\hline $\begin{array}{c}\text { Formulasi Penambahan } \\
\text { telur }\end{array}$ & Kadar serat kasar (\%)erat basah) \\
\hline $50 \%$ & $2,44 \pm 0,95$ \\
$75 \%$ & $2,99 \pm 0,93$ \\
$100 \%$ & $2,94 \pm 0,36$ \\
$125 \%$ & $2,82 \pm 1,67$ \\
\hline
\end{tabular}

4. Kadar Karbohidrat Blondies Garut

Kadar karbohidrat tertinggi pada blondies dengan formulasi penambahan telur adalah blondies dengan penambahan telur $50 \%$, sedangkan kadar karbohidrat terendah adalah blondies dengan penambahan telur
100\%. Hasil uji statistik menunjukkan ada pengaruh persentase penambahan telur terhadap kadar karbohidrat dengan $\mathrm{p}=0,000$. Hasil analisa kadar karbohidrat blondies dengan penambahan telur secara singkat dapat dilihat pada Tabel 4 .

Tabel 4. Hasil analisis karbohidrat blondies garut dengan formulasi penambahan telur

\begin{tabular}{cc}
\hline $\begin{array}{l}\text { Formulasi Penambahan } \\
\text { telur }\end{array}$ & Kadar Karbohidrat (\%berat basah) \\
\hline $50 \%$ & $43,39 \pm 0,73^{\mathrm{a}}$ \\
$75 \%$ & $37,03 \pm 0,55^{\mathrm{b}}$ \\
$100 \%$ & $27,42 \pm 0,78^{\mathrm{d}}$ \\
$125 \%$ & $31,14 \pm 2,05^{\mathrm{c}}$ \\
\hline
\end{tabular}

5. Volume kembang

Hasil uji volume kembang blondies garut dengan formulasi penambahan telur yang memiliki volume kembang tertinggi adalah blondies dengan penambahan telur $50 \%$, sedangkan volume kembang terendah adalah blondies dengan penambahan telur $125 \%$. Hasil uji statistik menunjukkan bahwa ada pengaruh persentase penambahan telur terhadap penurunan volume kembang dengan $\mathrm{p}=0,000$. 
Tabel 5. Hasil Analisis Volume Kembang Blondies Garut Dengan Formulasi Penambahan Telur

\begin{tabular}{lc}
\hline $\begin{array}{l}\text { Formulasi Penambahan } \\
\text { telur }\end{array}$ & Volume Kembang \\
\hline $50 \%$ & $39,00 \pm 1,54^{\mathrm{a}}$ \\
$75 \%$ & $29,17 \pm 1,16^{\mathrm{b}}$ \\
$100 \%$ & $19,50 \pm 0,83^{\mathrm{c}}$ \\
$125 \%$ & $19,17 \pm 0,98^{\mathrm{c}}$ \\
\hline
\end{tabular}

6. Uji kesukaan

Uji kesukaan dilakukan untuk mengetahui tingkat kesukaan suatu produk oleh konsumen. Faktor yang mempengaruhi uji kesukaan suatu produk adalah aroma, warna, tekstur, dan rasa.

a. Aroma

Uji kesukaan panelis terhadap aroma secara keseluruhan cukup baik dan disukai. Aroma blondies yang paling disukai adalah blondies dengan penambahan telur $100 \%$, sedangkan aroma blondies yang paling rendah tingkat kesukaannya adalah blondies dengan penambahan telur sebanyak $125 \%$. Uji statistik dengan nilai $p=0,162$ menunjukkan persentase penambahan telur tidak berpengaruh terhadap uji kesukaan aroma blondies. Uji kesukaan terhadap aroma blondies dapat dilihat pada Tabel 6 .

Tabel 6. Uji kesukaan Terhadap Aroma Blondies

\begin{tabular}{|c|c|c|}
\hline $\begin{array}{l}\text { Formulasi Penambahan } \\
\text { telur }\end{array}$ & $\begin{array}{c}\text { Kesukaa } \\
\mathrm{n}\end{array}$ & Keterangan \\
\hline $50 \%$ & 3,95 & suka \\
\hline $75 \%$ & 4,10 & suka \\
\hline $100 \%$ & 4,15 & suka \\
\hline $125 \%$ & 3,80 & suka \\
\hline
\end{tabular}

b. Warna

Warna blondies yang paling
disukai adalah blondies dengan penambahan telur $100 \%$, sedangkan warna blondies yang paling rendah tingkat kesukaannya adalah blondies dengan penambahan telur sebanyak 50\%.
Uji statistik menunjukkan bahwa persentase penambahan telur berpengaruh terhadap uji kesukaan warna blondies yang ditunjukkan dengan nilai $\mathrm{p}$ $=0,000$. Uji kesukaan terhadap warna blondies dapat dilihat pada Tabel 7.

Tabel 7. Uji kesukaan Terhadap Warna Blondies

\begin{tabular}{ccc}
\hline Formulasi Penambahan telur & Kesukaan & Keterangan \\
\hline $50 \%$ & $3,60^{\mathrm{c}}$ & Suka \\
$75 \%$ & $4,10^{\mathrm{ac}}$ & Suka \\
$100 \%$ & $4,65^{\mathrm{a}}$ & sangat suka \\
$125 \%$ & $4,15^{\mathrm{ab}}$ & Suka \\
\hline
\end{tabular}

c. Tekstur

$$
\begin{aligned}
& \text { Tekstur blondies yang paling } \\
& \text { disukai adalah blondies dengan } \\
& \text { penambahan telur 100\%, sedangkan } \\
& \text { tekstur blondies yang paling rendah } \\
& \text { tingkat kesukaannya adalah blondies } \\
& \text { dengan penambahan telur sebanyak } 75 \%
\end{aligned}
$$

akan tetapi secara keseluruhan tekstur blondies disukai oleh panelis. Persentase penambahan telur berpengaruh terhadap uji kesukaan tekstur blondies dibuktikan dengan nilai $\mathrm{p}=0,049$. Uji kesukaan terhadap tekstur blondies dapat dilihat pada Tabel 8.

Tabel 8. Uji kesukaan Terhadap Tekstur Blondies 


\begin{tabular}{ccc}
\hline Formulasi Penambahan telur & $\begin{array}{c}\text { Kesukaa } \\
n\end{array}$ & Keterangan \\
\hline $50 \%$ & $4,00^{\mathrm{d}}$ & Suka \\
$75 \%$ & $4,30^{\mathrm{c}}$ & Suka \\
$100 \%$ & $4,50^{\mathrm{a}}$ & Suka \\
$125 \%$ & $4,40^{\mathrm{b}}$ & Suka \\
\hline
\end{tabular}

d. Rasa

Uji kesukaan panelis terhadap rasa blondies secara keseluruhan cukup baik dan disukai. Rasa blondies yang paling disukai adalah blondies dengan penambahan telur $100 \%$, sedangkan rasa blondies yang paling rendah tingkat kesukaannya adalah blondies dengan penambahan telur sebanyak 50\%. Uji statistik menunjukkan bahwa persentase penambahan telur tidak berpengaruh terhadap uji kesukaan rasa blondies dengan nilai $\mathrm{p}=0,184$. Uji kesukaan terhadap rasa blondies dapat dilihat pada Tabel 9.

Tabel 9. Uji kesukaan Terhadap Rasa Blondies

\begin{tabular}{lcc}
\hline $\begin{array}{l}\text { Formulasi Penambahan } \\
\text { telur }\end{array}$ & Kesukaan & Keterangan \\
\hline $50 \%$ & 4,30 & suka \\
$75 \%$ & 4,50 & suka \\
$100 \%$ & 4,65 & suka \\
$125 \%$ & 4,43 & suka \\
\hline
\end{tabular}

\section{PEMBAHASAN}

\section{Protein}

Hasil penelitian menunjukkan kadar protein blondies garut makin meningkat bersamaan dengan meningkatnya persentase penambahan telur. Hal ini dikarenakan kadar protein telur $(12,8 \%)$ yang lebih tinggi dibandingkan dengan kadar protein tepung garut $(1,78 \%)$. Selain itu komposisi asam amino dalam telur cukup lengkap sehingga dapat melengkapi asam amino dalam tepung garut.

Meskipun demikian, masih terjadi kehilangan protein sebesar $0,49 \%$ pada penambahan telur $50 \%$ dan $0,87 \%$ pada penambahan telur $75 \%$, yang disebabkan oleh proses pengolahan (cooking loss) blondies garut. Kerusakan akibat cooking loss dapat terjadi karena reaksi Maillard. Reaksi Maillard adalah reaksi antara gula reduksi dengan protein pada suhu $150-260^{\circ} \mathrm{C}$ yang membentuk warna coklat pada makanan. Pada reaksi ini asam-asam amino terutama lisin berikatan dengan glukosa dan fruktosa membentuk produk akhir melanoidin, protein termodifikasi dan senyawa aromatik seperti trimetil pirazin, tetrametil pirazin, benzaldehida, fenil asetaldehida dan senyawa lainnya yang merupakan sumber aroma khas dalam produk reaksi Maillard dan cenderung bersifat volatil sehingga dapat menguap dan menyebabkan cooking loss. ${ }^{2}$

Selain itu, hilangnya asam-asam amino esenssial dalam reaksi Maillard bersifat irreversible dan produk akhir yang dihasilkan dari reaksi ini tidak dapat dicerna dalam tubuh karena tidak tersedia enzim untuk mengubah protein termodifikasi menjadi asam amino, sehingga bioavailabilitasnya menurun. ${ }^{13}$ Penurunan bioavailabilitas harus dihindari terutama pada produk yang ditujukan untuk anak-anak, agar asam amino esensial yang terkandung dalam makanan dapat terserap maksimal untuk menunjang pertumbuhan dan perkembangan anak.

Protein sebagai zat pembangun, memiliki fungsi utama untuk membentuk jaringan dan mempertahankan jaringan yang telah ada. Pembentukan jaringan ini merupakan proses penting yang menunjang masa pertumbuhan dan perkembangan pada bayi serta anak-anak. Selain itu, protein juga digunakan sebagai bahan bakar apabila kebutuhan energi tubuh tidak terpenuhi oleh karbohidrat dan lemak. ${ }^{14}$ Sumbangan blondies garut dengan penambahan telur sebanyak $125 \%$ terhadap AKG protein untuk anak usia 
4-6 tahun sebesar 19,07\% dan untuk anak usia 7-9 tahun sebesar $16,53 \%$.

\section{Lemak}

Penambahan telur terbukti berpengaruh terhadap penurunan lemak pada blondies. Penambahan telur dapat menyebabkan meningkatnya kadar air dan berat pada setiap formulasi sehingga persentase lemak semakin menurun. Selain itu penurunan lemak kemungkinan disebabkan rusaknya lemak pada saat proses pengolahan dengan pemanasan Semakin lama dan semakin tinggi suhu yang digunakan saat pengolahan maka kerusakan lemak akibat hidrolisis akan semakin besar.

Semakin banyak penambahan telur, maka semakin tinggi kadar air dalam produk sehingga kemungkinan terjadinya hidrolisis semakin besar. Dengan demikian semakin banyak asam lemak bebas dan gliserol yang terbentuk. Gliserol mempunyai sifat dapat larut dalam air dan tidak larut dalam eter dan hexane sehingga tidak terhitung dalam proses pengujian lemak. ${ }^{15}$

Lemak makanan berperan penting dalam pencernaan, absorbsi dan transportasi vitamin larut lemak, serta senyawa fitokimia seperti karotenoids dan lycopenes. Konsumsi lemak yang cukup dapat membantu memenuhi kebutuhan energi untuk anak-anak, sehingga protein tidak ikut dipecah menjadi energi dan obesitas dapat dihindari. ${ }^{16}$

\section{Serat Kasar}

Penambahan telur dalam pembuatan blondies garut tidak berpengaruh terhadap kadar serat kasar blondies. Secara statistik tidak ada perbedaan yang bermakna pada kadar serat semua perlakuan. Hal ini disebabkan telur tidak memiliki serat sehingga kadar serat hanya berasal dari tepung umbi garut saja yaitu sekitar 2,59\%.

Sumbangan blondies garut terhadap kebutuhan serat untuk anak yaitu sebesar $18,65 \%$ per 100 gram sajian. Konsumsi serat yang dianjurkan untuk anak-anak adalah sebesar 15 gram sehari sesuai kebutuhan. Pada anak dengan sindrom autisme serat dalam pencernaan berfungsi untuk memberi sifat bulky dalam feses, sehingga membantu mengurangi gejala diare yang sering terjadi. ${ }^{17}$

\section{Karbohidrat}

Secara umum kadar karbohidrat dalam blondies garut mengalami penurunan. Hal ini disebabkan kadar karbohidrat tepung garut sebesar 64,39\% yang lebih tinggi dibanding dengan kadar karbohidrat telur yaitu $0,7 \%$. Kadar karbohidrat pada blondies garut secara umum mengalami penurunan dengan penambahan telur. Penurunan ini dapat dipengaruhi oleh metode perhitungan by difference dimana seiring dengan peningkatan kadar protein dan perubahan kadar lemak, kadar karbohidrat yang merupakan hasil selisih perhitungan akan semakin menurun. Selain itu juga dipengaruhi oleh penambahan telur yaitu semakin banyak penambahan telur, semakin tinggi kadar air dan berat adonan sehingga persentase kadar karbohidrat menurun.

Kebutuhan energi untuk anak-anak ditentukan berdasarkan metabolisme basal, status pertumbuhan, dan aktivitas anak. Pada anak-anak yang masih dalam masa pertumbuhan dan disertai dengan aktivitas yang cukup tinggi, karbohidrat merupakan sumber zat gizi yang penting untuk dipenuhi kecukupannya. ${ }^{18}$ Sebagai sumber energi utama, kecukupan karbohidrat berfungsi untuk menunjang pertumbuhan dan perkembangan anak-anak, seperti mencegah terjadinya pemecahan protein yang berlebihan untuk diubah menjadi energi.

\section{Volume Kembang}

Karakteristik produk bakery meliputi dimensi, volume, penampakan, warna dan formasi remah merupakan faktor-faktor yang mempengaruhi nilai dari produk bakery tersebut. Volume kembang pada blondies garut secara umum mengalami penurunan. Hal ini disebabkan penambahan kuning telur yang mengandung lemak dapat menyebabkan blondies tidak dapat mengembang dengan baik. Dengan demikian semakin banyak penambahan kuning telur volume kembang akan semakin menurun. ${ }^{19}$ Berbeda dengan putih telur berfungsi untuk membentuk tekstur dan pengembangan dalam adonan karena sifatnya yang dapat memerangkap udara.

Secara keseluruhan penambahan telur dalam pembuatan blondies berfungsi sebagai pembentuk tekstur, rasa, aroma dan juga berpengaruh terhadap volume kembang. Selain itu lemak berfungsi untuk memberikan 
rasa gurih, warna dan aroma yang khas serta memberikan teksur lembut sehingga roti mudah digigit.

\section{Uji kesukaan}

\section{a. Aroma}

Uji kesukaan aroma blondies garut menurun pada penambahan telur paling banyak, meskipun demikian secara umum aroma blondies disukai oleh panelis. Semakin banyak penambahan telur, semakin amis aroma blondies. Aroma amis ini disebabkan oleh penguraian berbagai senyawa yang berasal dari hasil penguraian asam-asam amino. $^{20}$ Penambahan essens aroma pandan bertujuan untuk mengurangi bau amis dari telur, sehingga panelis dapat menerima aroma blondies garut yang dibuktikan dengan hasil uji penambahan telur terhadap uji kesukaan aroma blondies menunjukkan tidak ada pengaruh yang signifikan.

\section{b. Warna}

Dalam uji organoleptik, rasa tertarik akan timbul setelah melihat warna suatu produk. Uji kesukaan aroma blondies garut cenderung menurun pada penambahan telur paling banyak, akan tetapi secara umum warna blondies disukai oleh panelis, terutama blondies dengan penambahan telur $100 \%$. Hal ini disebabkan semakin banyak penambahan telur, warna yang dihasilkan semakin terang dan menarik, sedangkan semakin sedikit telur yang ditambahkan mengakibatkan warna blondies semakin gelap dan pucat. Pada penambahan telur terbanyak uji kesukaan panelis kembali menurun disebabkan warna yang dihasilkan terlalu muda dan pucat. Hal ini terjadi karena essens yang digunakan jumlahnya tetap, sedangkan dengan meningkatkanya penambahan telur kandungan air dalam adonan akan semakin meningkat, sehingga warna yang dihasilkan semakin muda. Warna yang terang dan menarik lebih disukai oleh panelis, dibuktikan dengan hasil uji penambahan telur terhadap uji kesukaan warna blondies menunjukkan ada pengaruh yang signifikan.

\section{c. Tekstur}

Blondies merupakan salah satu jenis sponge cake yang memiliki tekstur lembut. Uji kesukaan tekstur blondies garut cenderung menurun pada penambahan telur paling banyak, meskipun begitu panelis cukup menyukai tekstur blondies garut. Pada blondies dengan penambahan telur $50 \%$ tekstur yang dihasilkan agak keras dan cenderung berpori. Penurunan uji kesukaan pada penambahan telur terbanyak disebabkan karena tekstur blondies menjadi terlalu lembek. Hal ini disebabkan karena lemak berfungsi memberikan tekstur yang empuk, sehingga seiring dengan penambahan telur terjadi peningkatan lemak yang berasal dari kuning telur dan semakin lembut pula tekstur yang dihasilkan. ${ }^{21}$ Selain itu kadar air yang tinggi karena penambahan telur dan proses pengukusan serta penggunaan tepung garut dalam jumlah yang sama dalam setiap formulasi menyebabkan air menempati ronggarongga adonan sehingga tekstur blondies semakin lama semakin lembut dan terasa lembab. ${ }^{22}$ Tekstur yang cukup empuk lebih disukai oleh panelis, dibuktikan dengan hasil uji penambahan telur terhadap uji kesukaan terkstur blondies menunjukkan ada pengaruh yang signifikan.

\section{d. Rasa}

Rasa merupakan parameter uji kesukaan panelis terhadap suatu produk, meskipun parameter lain dinilai cukup baik tetapi apabila rasanya tidak disukai makan produk tersebut tidak akan dikonsumsi lagi. Uji kesukaan rasa blondies garut cenderung menurun pada penambahan telur paling banyak, akan tetapi secara keseluruhan rasa blondies disukai oleh panelis. Hal ini dapat disebabkan karena penambahan madu dengan jumlah yang sama pada setiap formulasi. Hal ini menyebabkan rasa manis yang semakin berkurang seiring dengan penambahan telur, sehingga pada penambahan telur terbanyak blondies terasa kurang manis. Hasil uji penambahan telur terhadap uji kesukaan rasa panelis menunjukkan tidak ada pengaruh yang signifikan. 


\section{SIMPULAN}

1. Penambahan telur pada pembuatan blondies garut secara bermakna berpengaruh terhadap peningkatan kadar protein serta uji kesukaan panelis akan warna dan tekstur.

2. Penambahan telur pada pembuatan blondies garut secara bermakna berpengaruh terhadap penurunan kadar lemak, karbohidrat dan volume kembang.

3. Penambahan telur pada pembuatan blondies garut tidak berpengaruh pada kadar serat kasar serta uji kesukaan panelis akan rasa dan aroma

4. Berdasarkan nilai kandungan zat gizi dan uji kesukaan, blondies terbaik adalah blondies dengan penambahan telur sebanyak $100 \%$.

\section{SARAN}

Penambahan telur dapat dilakukan secara parsial dengan memisahkan putih dan kuning telur agar didapatkan volume pengembangan yang lebih baik

\section{DAFTAR PUSTAKA}

1. American Psychiatric Association (APA). Diagnostic and statistical manual of mental disorders $4^{\text {th }}$ ed. Washington, DC; 2000.

2. Kogan MD, Blumberg SJ, Schieve LA, Boyle CA, Perrin JM, Ghandour RM et al. Prevalence of Parent-Reported Diagnosis of Autism Spectrum Disorder Among Children In The US 2007. Pediatrics 2009;124;1395.

3. Bauman ML, Kemper TL, editors. The Neurobiology Of Autism. The John Hopkins University Press; 2005. p. 109-110.

4. Melly Budiman. Gangguan Metabolisme Pada Anak Autistik di Indonesia (makalah), Jakarta: Konferensi Nasional Autism - 1. 2003.

5. Vaclavic VA, Christian EW. Essentials of Food Science $3^{\text {rd }}$ ed. Springer; 2008. p. 352.

6. PERSAGI. Tabel Komposisi Pangan Indonesia. Jakarta: Penerbit PT Kompas Gramedia; 2009. P. $1,3,19$.

7. Adi N Wicaksono. Nippon Indosari Corpindo: Bread Master in Expansionary Mode. PT Kim Eng Securities; 2012.

8. Christina Noor Sulistyo. Pengembangan Brownies Kukus tepung Ubi Jalar di PT. Fits Mandiri Bogor [skripsi]. Bogor: Institut Pertanian Bogor; 2006.

9. Adams JB. Summary of Biomedical Treatments for Autism. ARI Publication 40; 2007.

10. Abdul Rohman Sumantri. Analisis Makanan. Yogyakarta: Gajah Mada University Press; 2007.

11. Cauvain SP, Young LS. Technology of bread making $2^{\text {nd }}$ ed. Springer; 2007. p. 11-13

12. Deddy Muchtady. Teknik Evaluasi Nilai Gizi Protein. Alfabeta; 2009. p. 84-86
13. Gian Puspita Apriyana. Pengaruh pengolahan Terhadap Kandungan Proksimat, Asam Amino dan Taurin Keong Ipong Ipong [Skripsi]. Institut Pertanian Bogor; 2011.

14. Fayle SE, Gerrard J. The Maillard Reaction. Royal Society of Chemistry; 2002. p. 15.

15. Rodwell WV, Mayes AP, Gramer KD, Murray RK. Harper's Review of Biochemistry, 20 ${ }^{\text {th }}$ Ed., Aplleton and Lange, USA; 2000. p. 286.

16. Lucas BL, Feucht SA. Nutrition in childhood. In: Mahan LK, Stump SE. Krause's food and nutrition therapy. $12^{\text {th }}$ ed. Saunders Elsevier; 2008. p. 42, $224-241$.

17. Marsono, Wiyono, Utomo Zaki. Indeks glikemik produk olahan garut (Maranta arundinacea L.) dan uji sifat fungsionalnya pada model hewan coba. Kementrian Ristek. Jakarta; 2005.

18. Eni Harmayani, Ika Kumalasari, Y Marsono. Effect of arrowroot diet on the selected bacterial population and chemical properties of caecal digesta of Sprague Dawley rats. International Research Journal of Microbiology (IRJM) Vol. 2(8); 2011. p. 278-284.

19. Adams JB. Summary of Biomedical Treatments for Autism. ARI Publication 40; 2007.

20. Lucas BL, Feucht SA. Nutrition in childhood. In: Mahan LK, Stump SE. Krause's food and nutrition therapy. $12^{\text {th }}$ ed. Saunders Elsevier; 2008. p. $224-$ 241.

21. Suas M. Advanced Bread and Pastry: A Profesional Approach. Delmar; 2009. p. 480-481.

22. Bellitz HD, Grosch W, Schieberle P. Food Chemistry ed. $3^{\text {rd }}$. German: Springer; 2004. p. 107. 